\title{
LI. On the discharge of a jet of water under water
}

\section{R.W. Fox Esq.}

To cite this article: R.W. Fox Esq. (1830) LI. On the discharge of a jet of water under water , Philosophical Magazine Series 2, 8:47, 342-342, DOI: 10.1080/14786443008675468

To link to this article: http://dx.doi.org/10.1080/14786443008675468

曲 Published online: 10 Jul 2009.

Submit your article to this journal

III Article views: 1

Q View related articles $\sqsubset$ 


\subsection{Prof. Bessel's Additions to the Theory of Eclipses,}

The whole of the foregoing remarks are submitted, with much deference, to the consideration of geologists ; as supplementary to Dr. Macculloch's memoirs on the concretionary structure in rocks, and as hints, for future investigation, by those who have it in their power to institute extensive researches in Geology.

Hazel wood School, near Birmingham, Oct. 10 th, 1830.

LI. On the Discharge of a Jet of Water under Water. By R. W. Fox, Esq.

To the Editors of the Philosophical Magazine and Annals.

T AM not aware that it has been before noticed, that a jet of water discharges the same quantity, in water, as in air, in a given time, withoint reference to the depth or the motion of the water; at least within certain limits.

'Thus when the experiment was tried with a head of watersix feet high, the same orifice discharged equal quantities in equal times in air, in still water, and in a rapid stream, moving at the rate of about six feet in a second ; the jet having in one case been turned with the current, and in another against it: and when by lengthening the tube, the aperture was submerged to the depth of fifteen feet, the effect was the same as at the surface, under the pressure of an equal column above it.

These results have been obtained by my brother Alfred Fox, and myself; - and you may, perhaps, think them deserving a place in your Magazine, if they should appear to you to be new.

We sometimes coloured the water, when the jet appeared to pass unbroken to a considerable distance under the water.

Falmouth, 10th month, 9th, 1830.

R. W. Fox.

LII. Additions to the Theory of Eclipses, and the Methods of calculating their Results. By Professor BEssen.

[Continued from page 275.]

[7.] THE calculation of an occultation of a star can now be performed, after the preparatory operations explained in the preceding section, in two different ways. The first supposes that the same value of $T$ is to be applied to all observations which are to be calculated, in which case $p$ and $g$ correspond to the value $a$ in the arrangement above given. On 